Open Access

\title{
The Common Agricultural Policy 2014-2020: scenarios for the European agricultural and rural systems
}

\author{
Concetta Nazzaro ${ }^{*}$ and Giuseppe Marotta
}

\author{
* Correspondence: cnazzaro@ \\ unisannio.it \\ Department of Law, Economics, \\ Management and Quantitative \\ Methods, University of Sannio, \\ Benevento, Italy
}

\begin{abstract}
The reform of Common Agricultural Policy for 2014-2020 aims at promoting greater competitiveness, efficient use of public goods, food security, preservation of the environment and specific action against climate change, social and territorial equilibrium, and a more inclusive rural development. The economic crisis of the last years, the globalization, the increasing pressure on natural resources, the increasing diversity of agriculture and rural areas in the new enlarged Europe, and citizens' expectations regarding the environment, safety and food quality, health and welfare, preservation of the countryside, biodiversity and climate change, and the unequal distribution of resources are some of the major issues that this policy has faced, in a production context directed by principles of fairness and efficiency.

The policy instruments to address these challenges and achieve specific objectives appear greatly transformed and made up of two complementary pillars (direct payments and market measures, the first, and rural development, the second). The perspectives that the new Common Agricultural Policy provides in order to reach a competitive repositioning of the European agricultural and rural systems have been the theme of the 51st SIDEA Conference aimed at promoting a scientific debate on implementation of this policy in Italy.

The papers selected for this special issue focus on the new perspectives for European farms, agri-food supply chains, and rural territories of the new Common Agricultural Policy.

Keywords: Sustainability supply chain, Farm diversification, Common Agricultural Policy
\end{abstract}

\section{Background}

Agriculture is an essential component of European economy and society. For this reason, the new Common Agricultural Policy (CAP) aims at promoting greater competitiveness, efficient use of public goods, food security, respect of the environment and action against climate change, and social and territorial equilibrium. These goals are included within the main objective of a sustainable, smart, and inclusive growth of the rural Europe in the "Europe 2020 Strategy."

To this end, the CAP 2014-2020 is based on a first pillar, promoting "greener" and more equally shared support, and on a second one, more focused on competitiveness, innovation, climate change, and environment. Reserving support only to "active" farmers and remunerating the collective services (public goods) which they provide to society enhance the

(c) 2016 The Author(s). Open Access This article is distributed under the terms of the Creative Commons Attribution 4.0 International License (http://creativecommons.org/licenses/by/4.0/), which permits unrestricted use, distribution, and reproduction in any medium, provided you give appropriate credit to the original author(s) and the source, provide a link to the Creative Commons license, and indicate if changes were made. 
effectiveness and efficiency of policy instruments and help to legitimize the CAP and, in general, to strengthen the social role of agriculture (Marotta and Nazzaro 2013).

Essentially, the CAP reform for the period 2014-2020 aims at making the European agricultural sector more dynamic, competitive, and effective in pursuing the objective of the EC Communication "The CAP towards 2020: meeting the food, natural resources and territorial challenges of the future" (European Commission, 2010). The reform therefore highlights many unresolved issues, some of which are strategic and need a broader scientific debate discussing the main themes, to which the policy refers, and its implications for European agriculture. It seeks to address in an unprecedented global scenario economic, environmental, and social challenges.

The economic crisis, the market globalization, the increasing pressure on natural resources, the increasing diversity of agriculture and rural areas due to the enlargements of the EU, and citizens' expectations regarding the environment, safety and food quality, health and welfare, preservation of the countryside, ecosystem services, biodiversity and climate change, and the unequal distribution of resources are some of the major issues that this policy has faced, in a production context directed by principles of fairness and efficiency.

The necessary instruments to address these challenges and achieve specific objectives appear greatly transformed and made up of two complementary pillars; the first is focused on direct payments and market measures and the second on the multi-annual measures of rural development.

About the direct payments, the European Commission outlines the importance of a redistribution, redesign, and better targeting of the support, based on objective and equitable criteria, easy to understand by the taxpayer. These criteria should be both economic (noting the "income support" element of direct payments) and environmental (reflecting the public goods provided by farmers), with a better support targeted towards active farmers. A more equitable distribution of funds should be organized in an economically and politically feasible way with a transition to avoid major disruption.

The rural development policy (second pillar of the CAP) aims at promoting competitiveness, sustainable management of natural resources, and balanced development of rural areas by means of more specific measures, giving the Member States, through cofinancing, the flexibility to meet their priorities. This policy is strategic to face the European environmental challenges; therefore, the scientific debate on these issues is wide and articulated.

In the context of the present-day crisis, the innovations introduced in the rural development policy in terms of integrated intervention strategies and creation of local partnerships for a bottom-up governance of rural areas, realized through the Leader approach, become the strategic mission of new programming instruments. The multilevel governance processes of the integrated local development, with the active involvement of local stakeholders to mobilize material and immaterial resources, as part of a wider sharing of participatory development projects (Peterson 2013), are at the center of Community-Led Local Development for 2014-2020, as a model for collective and integrated action for programmed intervention on a territorial basis (European Commission 2014).

In summary, the new CAP should contribute to the development of a socially responsible and more balanced European agriculture, at the territorial and environmental levels.

Given such a framework, the 51st SIDEA Conference (Italian Society of Agricultural Economics), held in September 2014 at the University of Sannio, in Benevento (Italy), 
focused on the theme about "The Common Agricultural Policy 2014-2020: scenarios for the European agricultural and rural systems." This Conference aimed at promoting a scientific debate on the perspectives that the new CAP provides in order to reach a competitive repositioning of the European agricultural and rural systems, in particular, through the deep study of the following themes, organized in three plenary sessions: CAP 2014-2020 and new challenges for agriculture and rural areas; CAP 2014-2020 and market; and CAP 2014-2020 and rural development.

From one side, it seems appropriate to wonder whether the general policy decisions and the measures planned are really able to achieve the objectives set and the challenges of globalization. From the other side, the papers presented at the Conference develop analysis and reflections about predictable effects of the new Common Agricultural Policy configuration.

Five papers presented at the 51st SIDEA Conference have been selected for the Agricultural and Food Economics special issue focusing on the new European agricultural model and on the sustainability of the new rural policy. These were subjected to a peer review process before being accepted for publication.

\section{Report}

The growing consumer sensitivity about environmental and health attributes of food products has led Galli, Bartolini, Brunori, Colombo, Gava, Grando, and Marescotti (Agricultural and Food Economics 2015, 3:21) to analyze, in the paper "Sustainability assessment of food supply chains: an application to local and global bread in Italy," the environmental impact which comes from traditional food supply chains. The study analyzes the chain of wheat-to-bread, focusing on the relationship between the geographical scope of the food chain and its sustainability, obtained by comparing the 19 attributes that express the different dimensions of sustainability. After a review of the literature on the sustainability of the supply chain processes (of wheat-to-bread chains), the paper proposes a qualitative assessment based on two Italian study cases, identifying critical aspects and providing a comparison between local and global supply chains.

In the paper "Empirical survey on business models of kindergarten farms," Torquati, Tancini, Paffarini, and Illuminati (Agricultural and Food Economics 2015, 3:25) analyze two cases of Italian kindergarten which took part in a special project promoted by the Marche Region, to improve the quality of life in rural areas. The authors highlight the importance of the synergy between agriculture and the education sector and local and regional institutions, in order to carry out social functions for the creation of collective well-being. The Business Model Canvas has allowed to analyze the economical results of educational farms, the farm's relevance as a place of education, and the role of decision-makers, demonstrating how this diversification of activities in rural areas allows farms to increase income, promote generational change and, in particular, women's employment, and reduce the costs of public social services.

The price asymmetries along the chain of pasta are subject of attention in the paper "Antitrust intervention and price transmission in pasta supply chain" by Luca Cacchiarelli and Alessandro Sorrentino (Agricultural and Food Economics 2016, 4:2). The paper analyzes the pasta market, a strategic product in the Italian agro-food industry. During the last several years, many events have affected the Italian pasta supply chains, the CAP Reform, and price instability. The study analyzes a case of 
anti-competitive practices against makers of pasta, who have been identified and sanctioned by the Italian Antitrust Authority for the period between October 2006 and March 2008. The authors' objective was to determine whether the antitrust action has produced some substantial effects on the market of Italian pasta, restoring a state of considerable competition among businesses. For the study, the Kinnucan and Forker model has been employed which is used in the literature to analyze the impact of a policy intervention on farm-to-retail price transmission. Results show that analysis of the transmission price between semolina and pasta has highlighted that antitrust intervention would have produced some substantial effects in the Italian pasta market by restoring a state of appreciable competition among companies.

Global population growth and the consequent increase in consumption have led to an increase in the demand of food and energy both in developed and developing countries. It has produced an intensification of land investments that, in most cases, has not respected the rules and did not contribute to the development of local communities. The target of Carroccio, Crescimanno, Galati, and Tulone in the paper "The land grabbing in the international scenario: the role of the EU in land grabbing" (Agricultural and Food Economics 2016, 4:12) is to identify, through a cluster analysis, the drivers of investor countries and assess if EU Member States take a common behavior in the context of the so-called land grabbing. The analysis, carried out from 2000 to 2013, led to the identification, based on specific socio-economic and environmental variables, of four homogeneous groups of countries. The results show that, especially for the EU Member States for which energy efficiency and reducing $\mathrm{CO}_{2}$ emissions are priority objectives (as in the "Europe 2020 Strategy"), the adopted strategies are driven by the need to achieve energy and food security and to reduce pollutant emissions into the atmosphere.

Social agriculture is able to generate socio-economic benefits that are attracting, in Europe, the attention of several stakeholders. This is demonstrated by Bassi, Nassivera, and Pianiin in the study "Social farming: a proposal to explore the effects of structural and relational variables on social farm results" (Agricultural and Food Economics 2016, 4:13) which is part of a project carried out by the health authority of Friuli Venezia Giulia in order to analyze, through a structural equation model, the socio-economic impact of social farms in the area and, in particular, how this depends on the company's internal resources (corporate assets) and the external environment (relations). The analysis shows that the performance of social farms is mainly influenced by relational variables, while structural ones do not show direct influence, pointing out that to improve social impacts generated by farms, structural investments should be supported by a strong relational network at the local level.

\section{Conclusions}

Taken together, this collection of articles underlines the importance of the social role that the European agricultural model performs nowadays, through the production of public goods and services in favor of a new community welfare model. The studies presented explore the effects on sustainability and welfare of local communities which come from practices of diversification and multi-functionality, also in terms of land grabbing, highlighting efficient and effective results of the different policies. 


\section{Acknowledgements}

The authors would like to thank the Agricultural and Food Economics journal for having given visibility to the five papers presented at the 51st SIDEA Conference, contributing to promote the international diffusion of Italian agricultural economists' debate about strategic themes for future development of rural policy.

The papers selected for this special issue focus on the new perspectives for European farms, agri-food supply chains, and rural territories of the new Common Agricultural Policy.

\section{Authors' contribution}

CN partecipated in the background and report od the study; GM conceived the study and in itsorganization.

\section{Authors' information}

G. Marotta is a full professor of the Agri-Food Economics at the University of Sannio.

C. Nazzaro is an assistant professor of the Agri-Food Economics at the University of Sannio.

\section{Competing interests}

The authors declare that they have no competing interests.

Received: 8 July 2016 Accepted: 18 July 2016

Published online: 26 July 2016

\section{References}

European Commission (2010) The CAP towards 2020: meeting the food, natural resources and territorial challenges of the future., Bruxelles.COM(2010) 672 final

European Commission (2014) Guidance on Community-Led Local Development. Bruxelles

Marotta G, Nazzaro C (2013) Approcci integrati e governance locale nelle strategie di sviluppo rurale: un framework per la futura programmazione. Riv Econ Agrar 3:89-120

Peterson C (2013) Fundamental principles of managing multi-stakeholder engagement. International Food and Agribusiness Management Review. vol. 16 A, special issue. pp. 11-22

\section{Submit your manuscript to a SpringerOpen ${ }^{\circ}$ journal and benefit from:}

- Convenient online submission

- Rigorous peer review

- Immediate publication on acceptance

- Open access: articles freely available online

- High visibility within the field

- Retaining the copyright to your article 